\title{
Breast cancer in Mexican women: an epidemiological study with cervical cancer control
}

Câncer de mama em mulheres mexicanas: estudo epidemiológico com controles de câncer cervical

Víctor Tovar-G uzmána, Carlos Hernández-Giróna, Eduardo Lazcano-Poncea, Isabelle Romieu $^{b}$ and Mauricio Hernández Avila ${ }^{a}$

aResearch Center for Population Health. National Institute of Public Health. Cuernavaca M or, México. ${ }^{b}$ Centers for Disease Control and Prevention (CDC). Atlanta, Georgia, USA 


\title{
Breast cancer in Mexican women: an epidemiological study with cervical cancer control \\ Câncer de mama em mulheres mexicanas: estudo epidemiológico com controles de câncer cervical
}

\author{
Víctor Tovar-Guzmána , Carlos Hernández-Girónª, Eduardo Lazcano-Poncea, \\ Isabelle Romieub and Mauricio Hernández Avilaa
}

aResearch Center for Population Health. National Institute of Public Health. Cuernavaca M or, México. ${ }^{b}$ Centers for Disease Control and Prevention (CDC). Atlanta, Georgia, USA

\section{Keywords}

Breast neoplasms, epidemiologic\#.

Cervix neoplasms, prevention \&

control\#. U terine neoplasms, prevention \& control\#. Risk factors". Breast neoplasms. Mexican women.

\begin{abstract}
Introduction

In Mexico, breast cancer (BC) is one of the main causes of cancer deaths in women, with increasing incidence and mortality in recent years. Therefore, the aim of the study is identify possible risk factors related to BC.

Methods

An epidemiological study of hospital cases of BC and controls with cervical uterine cancer (CUCA) was carried out at eight third level concentration hospitals in Mexico City. The total of 353 incident cases of BC and 630 controls with CUCA were identified among women younger than 75 years who had been residents of the metropolitan area of Mexico City for at least one year. Diagnosis was confirmed histologically in both groups. Variables were analyzed according to biological and statistical plausibility criteria. Univariate, bivariate and multivariate analyses were carried out. Cases and controls were stratified according to the menopausal hormonal status (pre and post menopause).

Results

The factors associated with $\mathrm{BC}$ were: higher socioeconomic level $(\mathrm{OR}=2.77 ; 95 \% \mathrm{CI}$ $=1.77-4.35)$; early menarche $(\mathrm{OR}=1.32 ; 95 \% \mathrm{CI}=0.88-2.00)$; old age at first pregnancy $(>31$ years: $\mathrm{OR}=5.49 ; 95 \% \mathrm{CI}=2.16-13.98)$ and a family history of $\mathrm{BC}$ $(\mathrm{OR}=4.76 ; 95 \% \mathrm{CI}=2.10-10.79)$. In contrast, an increase in the duration of the breastfeeding period was a protective factor ( $>25$ months: $\mathrm{OR}=0.38 ; 95 \% \mathrm{CI}=0.20$ - 0.70).

Conclusions

This study contributes to the identification of risk factors for BC described in the international literature, in the population of Mexican women. Breastfeeding appears to play an important role in protecting women from $\mathrm{BC}$. Because of changes in women's lifestyles, lactation is decreasing in Mexico, and young women tend not to breastfeed or to shorten the duration of lactation.
\end{abstract}


Descritores

Neoplasias mamárias, epidemiologia. Neoplasias do colo, prevenção e controle ${ }^{\#}$. Neoplasias uterinas, prevenção $e$ controle ${ }^{\#}$. Fatores de risco. Fatores socioeconômicos.

\section{Resumo}

\section{Objetivo}

O câncer de mama (CM) é uma das principais causas de morte por câncer em mulheres, no México, com aumento da incidência e da mortalidade nos últimos anos. $O$ estudo realizado objetivou identificar possiveis fatores de risco relacionados ao CM.

\section{Métodos}

Realizou-se um estudo epidemiológico de casos hospitalares de CM e de controles hospitalares com câncer cérvico-uterino (CACU) em oito hospitais de terceiro nível, na Cidade do México. Foram estudados 353 casos incidentes de CM e 630 controles com CACU, identificados entre mulheres com menos de 75 anos de idade, residentes na área metropolitana da Cidade do México pelo menos há um ano. O diagnóstico foi confirmado histologicamente em ambos os grupos. As variáveis foram analisadas de acordo com critérios aprovados biológica e estatisticamente. Foram efetuadas análises univariadas, bivariadas e multivariadas. Os casos e controles foram estratificados de acordo com o estado hormonal menopáusico (pré e pós-menopausa). Foi usado o odds ratio (OR) como método de associação com intervalos de confiança (IC) acima de $95 \%$.

\section{Resultados}

Os fatores associados com o CM foram: nível socioeconômico alto $(O R=2,77$ IC $95 \%$ 1,77-4,35); menarca prematura $(O R=1,32$ IC 95\% 0,88-2,00); idade acima de 31 anos quando da primeira gravidez $(O R=5,49$ IC 95\% 21,16-13,98) e um histórico familiar de CM (OR=4,76 IC 95\% 2,10 - 10,79). Por outro lado, um aumento na duração da amamentação foi um fator protetor ( $>25$ meses $O R=0,38$ IC $95 \%$ 0,20 - 0,77).

\section{Conclusões}

Os resultados contribuíram para a identificação de fatores de risco para o CM descritos na literatura internacional na população de mulheres mexicanas. A amamentação parece exercer importante papel na proteção do CM. Em virtude das mudanças no estilo de vida das mulheres, as mulheres jovens tendem a diminuir seu período de amamentação.

\section{INTRODUCTION}

In Mexico, cervical uterine cancer (CUCA) and breast cancer (BC) are the main causes of death from cancer in women. The number of new cases of CUCA and BC in 1996 was 15,312 and 9,175 , representing $18.1 \%$ and $10.8 \%$ of total malignant tumors respectively. ${ }^{12}$

Epidemiological risk factors for $\mathrm{BC}$, aside from sociodemographic characteristics such as age, socioeconomic level, occupation, marital status, ${ }^{4,7}$ include: life style factors such as diet, obesity, and sedentary life $;, 6$ genetic factors such as family history of $\mathrm{BC}^{1}$ and hormonal factors such as early menstruation and late menopause, nulliparity, pregnancy at an advanced age and use of oral contraceptives, all of which indicate specifically prolonged estrogenic exposures. ${ }^{8}$ Other risk factors for CUCA include: precocity in sexual activity, higher number of sexual partners, history of human papillomavirus infection, cervical trauma and certain nutritional factors. ${ }^{5}$

The present study had as its main objective to identify possible risk factors related to $\mathrm{BC}$, through an epidemiological study of hospital cases of $\mathrm{BC}$ and controls with CUCA, carried out at eight third level hospitals in Mexico City.

\section{METHODS}

During the period between September 1990 and December 1992, a study of hospital cases and controls was carried out. The subjects to be studied were taken from eight hospitals in Mexico City, selected from information generated by the National Cancer Record of the General Epidemiology Direction, belonging to the Health Secretariat. This center compiles information from reports of malignant tumors at $\mathbf{5 2}$ hospital units in Mexico City. The hospitals which were considered represent the diversity of institutions offering services within the health sector in Mexico.

For the study, 353 incident cases of $\mathrm{BC}$ and 630 controls with CUCA were identified among women younger than 75 years who had been residents of the metropolitan area of Mexico City for at least one year. The sample was obtained of the next hospitals: General Hospital and Woman's Hospital (Secretary of Public Health); Gynecology and Obstetrics $\mathrm{N}^{\mathrm{o}} 3$ 
and $\mathrm{N}^{\mathrm{o}} 4$ Hospitals (Mexican Institute of Social Security); "20 de noviembre" Hospital (State Worker's Institute of Services and Social Security); Militar Hospital (Secretary of Defense); Mexico Hospital and Metropolitan Hospital (Privates). Diagnosis in both groups was confirmed histologically, through a biopsy.

In this study, cases and controls were defined as those women interviewed at the oncology services of the participating hospitals, who presented clinical and cytological reasons to suspect the presence of $\mathrm{BC}$ and CUCA. Criteria for inclusion in the population to be studied were: incident cases, without previous treatment and with geographic residence of at least one year in the metropolitan area of Mexico City, as well as voluntary participation.

The team of interviewers was previously trained in the logistic aspects of this study. Information was obtained through the application of a questionnaire on risk factors and a cytopathological report on all subjects who participated in the study.

Variables were analyzed according to biological and statistical plausibility criteria. Univariate, bivariate and multivariate analyses were carried out, using the Stata 3.0 statistical software. ${ }^{13}$ In the analysis, stratification according to the menopausal hormonal status (pre and post menopause) was considered. In the univariate analysis, frequencies, distributions and missing values of the different data obtained from the survey were investigated.

In the bivariate analysis, a comparison of means of the continuous variables in cases and controls was carried out through the $t$ test. An index of socioeconomic status was developed as suggested by Bronfman et $a{ }^{2}{ }^{2}$ by combining five variables (number of people living in the house, number of rooms in the house excluding kitchen and bathroom, availability of drinking water, sanitary conditions, and education level of the head of the family). The Quetelet index, expressed in quartiles, was constructed based on the relationship between weight, expressed in kilograms, and squared height, expressed in meters.

To evaluate the association between selected risk factors an $\mathrm{BC}$, the odds ratio (OR) was used as an association method with confidence intervals (CI) up to $95 \%$, obtained from non conditional logistic regression models (likelihood ratio adjustment). The variables in the study were examined individually and then simultaneously for confounding effects (multivariate analysis). Test for lineal trend with increasing exposure was carried out using the chisquare test under the assumption of a lineal relation.

Table 1 - Means comparison of reproductive variables in breast cancer in Mexican women, México, DF, 1994.

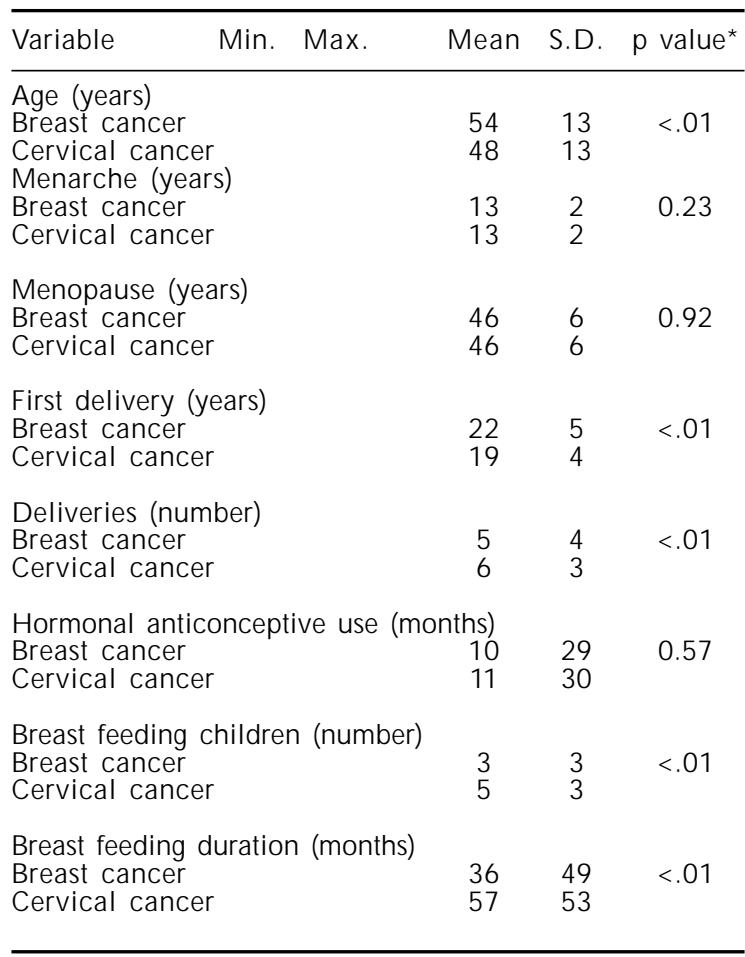

*Student t-TEST

S.D. - Standard Deviation

\section{RESU LTS}

The mean of age for cases was 54 years, and 48 for controls. This difference was statistically significant ( $\mathrm{p}=0.0000$ ) (Table 1). According to marital status, the highest percentage of cases and controls corresponded to married women $(61.4 \%$ and $52.6 \%$, respectively).

More cases (64.3\%) than controls (53.1\%) lived in urban areas. More cases (74.5\%) than controls (62.7\%) had access to social security services (IMSS). With respect to education level, $58.6 \%$ of cases and $56.1 \%$ of controls only had an elementary education. With respect to main occupation, $24.9 \%$ of cases and $27.3 \%$ of controls had an occupation different from housewives.

Low socioeconomic level was predominant in the controls, as compared to the cases $(40.9 \%$ and $19.3 \%$, respectively). Fewer cases (37\%) than controls (52.6\%) were post-menopausal. 
The mean of age for menarche, for cases and controls, was 13 years $(\mathrm{p}=0.2388)$. The mean of age for menopause, for both groups, was 46 years $(p=0.9257)$. The mean of age for the birth of the first child was 22 years for cases and 19 years for controls $(\mathrm{p}=0.0000)$. With respect to the number of deliveries, for cases the mean was 5 and for controls it was 6 $(\mathrm{p}=0.0000)$.

The mean of the duration of the breastfeeding period was 36 months for cases and 53 months for controls $(\mathrm{p}=0.0000)$. The mean of the duration of hormonal contraceptives use was 10 months for cases and 11 months for controls $(\mathrm{p}=0.5758)$ (Table 1).

With respect to the risk factors for $\mathrm{BC}$ (odds ratio = OR), several variables were analyzed and the following results were found: in terms of marital status, having lived together at some point in their lives, represented, in the raw analysis, protection against BC; however, in the adjusted analysis this relationship is not evident. Having lived in urban areas implied greater risk $(\mathrm{OR}=1.64 ; 95 \% \mathrm{CI}=1.08-2.47)$. Higher education level (university) was also associated with greater risk $(\mathrm{OR}=2.71 ; 95 \% \mathrm{CI}=1.05-7.00)$. High socioeconomic level also showed a positive association with increased risk for $\mathrm{BC}(\mathrm{OR}=2.77 ; 95 \% \mathrm{CI}=1.77-4.35)$.

In relation to reproductive variables, early menarche represented a greater risk $(\mathrm{OR}=1.32 ; 95 \% \mathrm{CI}=0.38$ 2.00). Older age at first pregnancy (> 31 years) was positively related to $\mathrm{BC}(\mathrm{OR}=5.49 ; 95 \% \mathrm{CI}=2.16-13.98)$. Having a higher number of children $(>7)$ was found to be a protective factor $(\mathrm{OR}=0.08 ; 95 \% \mathrm{CI}=0.03-0.17)$. The use of hormonal contraceptives ( $>=61$ months) was also associated with an increase in the risk of BC $(\mathrm{OR}=1.14 ; 95 \% \mathrm{CI}=0.60-2.16)$. A family history of $\mathrm{BC}$ increased the risk of this disease $(\mathrm{OR}=4.76 ; 95 \%$ $\mathrm{CI}=2.10-10.79)$ (Table 2).

The history of no breastfeeding was a risk factor $(\mathrm{OR}=2.65 ; 95 \% \mathrm{CI}=1.50-4.70)$. In contrast, an increase in the duration of the breastfeeding period $(>25$ months) was a protective factor $(\mathrm{OR}=0.38 ; 95 \% \mathrm{CI}=0.20$ -0.70 ) (Table 2).

The risk factors are differential by menopausal status. In the multivariate analysis, the factors possibly associated with $\mathrm{BC}$ were stratified according to the main confounding variable: menopausal status. In this way, the main characteristics associated with risk for $\mathrm{BC}$ in pre-menopausal women were determined to be: high socioeconomic level $(\mathrm{OR}=2.06 ; 95 \% \mathrm{CI}=1.02$ 4.19); early menarche ( $\mathrm{OR}=1.57$; $95 \% \mathrm{CI}=0.79-3.13)$; older maternal age at birth of first child ( $>31$ years) $(\mathrm{OR}=8.0 ; 95 \% \mathrm{CI}=1.50-43.65)$; family history of $\mathrm{BC}$
$(\mathrm{OR}=6.16 ; 95 \% \mathrm{CI}=1.86-20.39)$. In constrast, having a higher number of children $(>2)(\mathrm{OR}=0.10 ; 95 \% \mathrm{CI}=0.03$ $-0.32)$, and a history of breastfeeding and its duration (> 12 months) $(\mathrm{OR}=0.42 ; 95 \% \mathrm{CI}=0.16-1.13)$, were protective factors (Table 2 ).

Finally, the main risk characteristics associated with $\mathrm{BC}$ in post-menopausal women were: high socioeconomic level $(\mathrm{OR}=2.99 ; 95 \% \mathrm{CI}=1.66-5.41)$; early menarche $(\mathrm{OR}=1.15$; $95 \% \mathrm{CI}=0.68-1.96)$; maternal age at birth of first child ( $>31$ years) $(\mathrm{OR}=3.56$; $95 \% \mathrm{CI}=1.15-11.06)$; family history of $\mathrm{BC}(\mathrm{OR}=3.61$; $95 \% \mathrm{CI}=1.86-20.39)$. In contrast, the number of children $(>2)(\mathrm{OR}=0.22 ; 95 \% \mathrm{CI}=0.08-0.64)$, a history of breastfeeding and its duration (> 12 months) $(\mathrm{OR}=0.18 ; 95 \% \mathrm{CI}=0.05-0.47)$, were protective factors (Table 2).

\section{DISCUSSIO N}

The change in $\mathrm{BC}$ incidence rates with respect to age is influenced by the possible inclusion of reproductive hormones in the $\mathrm{BC}$ etiology. ${ }^{11} \mathrm{In}$ this study, the greatest frequency of BC occurred in women between ages 56 and 60 . We observed that the mean age in $\mathrm{BC}$ cases was higher than among controls with CUCA; this difference was similar in pre and postmenopausal women. These results are concordant to the international literature that show younger age for the appearence of CUCA.

Several studies done in different ethnic groups report that single women without previous sexual activity, older than 40 years of age, are at high risk for BC, compared to women who have been married. In our study, there is a non-significant association between civil status and risk for the disease. This can be attributed to the fact that women in the control group show high fertility rates. ${ }^{8,15}$

In the present study, women residing in urban areas from before age 15 were at a greater risk for BC, compared to those residing in suburban and rural areas. These results are similar to those reported in other countries.

In a similar manner, those women with a high socioeconomic level (SEL) had a greater risk for BC. This can be related to the fact that women with a higher SEL and more schooling have different life styles which include a diet rich in saturated fat, lower parity and a older age at their first pregnancy; these factors lead to greater estrogenic stimulation. ${ }^{15}$

The "estrogenic window", that is, early menses and late menopause - possible independent risk factors 
Table 2 - Odds ratios for breast cancer according to selected risk factors in Mexican women. Mexico city 1994.

\begin{tabular}{|c|c|c|c|c|c|c|}
\hline \multirow[b]{2}{*}{ Risk factor } & \multicolumn{2}{|c|}{ All Women } & \multirow{2}{*}{\multicolumn{2}{|c|}{$\begin{array}{cc}\text { Premenopausal women } \\
\text { OR* } & \text { IC } 95 \%\end{array}$}} & \multicolumn{2}{|c|}{ Post-menopausal women } \\
\hline & O R* & IC 95\% & & & & IC $95 \%$ \\
\hline $\begin{array}{l}\text { Socioeconomic level } \\
\text { Low } \\
\text { Medium } \\
\text { High } \\
\text { test for trend } p=0.000\end{array}$ & $\begin{array}{r}1.0 \\
1.58 \\
2.77\end{array}$ & $\begin{array}{l}1.08-2.33 \\
1.77-4.35\end{array}$ & $\begin{array}{l}1.0 \\
0.98 \\
2.06\end{array}$ & $\begin{array}{l}0.51-1.87 \\
1.02-4.19\end{array}$ & $\begin{array}{l}1.0 \\
2.06 \\
2.99\end{array}$ & $\begin{array}{l}1.26-33.9 \\
1.66-5.41\end{array}$ \\
\hline $\begin{array}{l}\text { Menarche (years) } \\
\quad<=12 \\
13 \\
14 \\
15 \\
>=16 \\
\text { test for trend } p=0.000\end{array}$ & $\begin{array}{l}1.32 \\
1.0 \\
1.31 \\
0.93 \\
0.59\end{array}$ & $\begin{array}{l}0.88-2.00 \\
0.82-2.08 \\
0.56-1.54 \\
0.28-1.25\end{array}$ & $\begin{array}{r}1.57 \\
1.0 \\
1.63 \\
1.03 \\
0.94\end{array}$ & $\begin{array}{l}0.79-3.13 \\
0.76-3.48 \\
0.40-2.63 \\
0.22-3.97\end{array}$ & $\begin{array}{l}1.15 \\
1.0 \\
1.15 \\
0.80 \\
0.46\end{array}$ & $\begin{array}{l}0.68-1.96 \\
0.63-2.11 \\
0.44-1.47 \\
0.19-1.11\end{array}$ \\
\hline $\begin{array}{l}\text { Age at first delivery (years) } \\
\quad<=20 \\
21-25 \\
26-30 \\
>=31 \\
\text { test for trend } p=0.000\end{array}$ & $\begin{array}{r}1.0 \\
1.58 \\
3.10 \\
5.49\end{array}$ & $\begin{array}{r}1.10 .2 .28 \\
1.81-5.33 \\
2.16-13.98\end{array}$ & $\begin{array}{r}1.0 \\
1.52 \\
4.00 \\
8.09\end{array}$ & $\begin{array}{r}0.84-2.77 \\
1.64-9.77 \\
1.50-43.65\end{array}$ & $\begin{array}{r}1.0 \\
1.57 \\
2.40 \\
3.56\end{array}$ & $\begin{array}{r}0.98-2.50 \\
1.21-4.75 \\
1.15-11.06\end{array}$ \\
\hline $\begin{array}{l}\text { Deliveries (number) } \\
\text { None } \\
1-2 \\
3-4 \\
5-6 \\
>=7 \\
\text { test for trend } p=0.000\end{array}$ & $\begin{array}{l}1.0 \\
0.22 \\
0.16 \\
0.13 \\
0.08\end{array}$ & $\begin{array}{l}0.10-0.49 \\
0.08-0.35 \\
0.59-0.29 \\
0.03-0.17\end{array}$ & $\begin{array}{l}1.0 \\
0.19 \\
0.10 \\
0.07 \\
0.02\end{array}$ & $\begin{array}{l}0.06-0.62 \\
0.03-0.32 \\
0.02-0.29 \\
0.01-0.10\end{array}$ & $\begin{array}{l}1.0 \\
0.23 \\
0.22 \\
0.17 \\
0.11\end{array}$ & $\begin{array}{l}0.08-0.71 \\
0.08-0.64 \\
0.06-0.50 \\
0.04-0.31\end{array}$ \\
\hline $\begin{array}{l}\text { Breastfeeding history } \\
\text { Yes } \\
\text { No } \\
\text { test for trend } p=0.000\end{array}$ & $\begin{array}{r}1.0 \\
2.65\end{array}$ & $1.50-4.70$ & $\begin{array}{r}1.0 \\
1.48\end{array}$ & $0.65-3.10$ & $\begin{array}{r}1.0 \\
5.90\end{array}$ & $2.06-16.90$ \\
\hline $\begin{array}{l}\text { Duration of breastfeeding (months) } \\
\begin{array}{l}0-3 \\
4-12 \\
13-24 \\
>=25 \\
\text { test for trend } p=0.000\end{array}\end{array}$ & $\begin{array}{l}1.0 \\
0.45 \\
0.30 \\
0.38\end{array}$ & $\begin{array}{l}0.24-0.86 \\
0.15-0.59 \\
0.20-0.70\end{array}$ & $\begin{array}{l}1.0 \\
0.81 \\
0.42 \\
0.87\end{array}$ & $\begin{array}{l}0.35-191 \\
0.16-1.13 \\
0.35-2.21\end{array}$ & $\begin{array}{l}1.0 \\
0.19 \\
0.18 \\
0.16\end{array}$ & $\begin{array}{l}0.06-0.63 \\
0.06-0.56 \\
0.05-0.47\end{array}$ \\
\hline $\begin{array}{l}\text { Duration of hormonal contraceptives } \\
\text { N one } \\
\begin{array}{l}1-12 \\
13-60 \\
>=61 \\
\text { test for trend } p=0.000\end{array}\end{array}$ & $\begin{array}{l}\text { use }(\mathrm{m} \\
1.0 \\
1.36 \\
1.59 \\
1.14\end{array}$ & $\begin{array}{l}0.76-2.44 \\
0.93-2.74 \\
0.60-2.16\end{array}$ & $\begin{array}{l}1.0 \\
1.43 \\
0.90 \\
0.79\end{array}$ & $\begin{array}{l}0.70-2.92 \\
0.43-1.87 \\
0.32-1.94\end{array}$ & $\begin{array}{r}1.0 \\
1.20 \\
4.84 \\
1.54\end{array}$ & $\begin{array}{r}0.42-3.48 \\
1.66-14.17 \\
0.55-4.31\end{array}$ \\
\hline $\begin{array}{l}\text { Family history of reast cancer } \\
\text { N } 0 \\
\text { Yes }\end{array}$ & $\begin{array}{r}1.0 \\
4.76\end{array}$ & $2.10-10.79$ & $\begin{array}{r}1.0 \\
6.16\end{array}$ & $1.86-20.39$ & $\begin{array}{r}1.0 \\
3.61\end{array}$ & $1.15-11.33$ \\
\hline $\begin{array}{l}\text { Q uetelet index (quartils) } \\
\quad 1 \\
2 \\
3 \\
4 \\
\text { test for trend } p=0.000\end{array}$ & $\begin{array}{l}1.0 \\
1.11 \\
1.16 \\
1.60\end{array}$ & $\begin{array}{l}0.70-1.75 \\
0.73-1.85 \\
1.02-2.50\end{array}$ & $\begin{array}{l}1.0 \\
1.13 \\
1.07 \\
2.87\end{array}$ & $\begin{array}{l}0.55-2.32 \\
0.51-2.25 \\
1.36-6.08\end{array}$ & $\begin{array}{l}1.0 \\
1.02 \\
1.15 \\
1.09\end{array}$ & $\begin{array}{l}0.55-1.87 \\
0.62-2.16 \\
0.61-1.96\end{array}$ \\
\hline
\end{tabular}

* Adjusted odds ratio by: age, socioeconomic level, family history, deliveries, age at first delivery, menopause status and Q uetelet index.

for BC. The increased risk associated with the prolonged duration suggest that the number of years of menstrual activity and, as a consequence, a greater exposure to estrogens, is an important etiological factor in this disease. ${ }^{8,14}$

In the study, evidence of a protective effect from late onset of age of menarche, was found, mainly for post-menopausal women. It has been suggested that the age of menarche is influenced by nutritional state and, consequently, by a high socioeconomic level.
In other studies, women with late menopause present double the risk for $\mathrm{BC}$ with respect to women with early menopause. For each five years of difference in the age of menopause, the risk for BC increases $17 \%$. In the present investigation, a 7\% greater risk for $\mathrm{BC}$ was found in post-menopausal women, compared to those who were pre-menopausal ones.

Nulliparity and older age of the mother at the birth of the first child have been indicated as BC risk factors. As an explanation for this finding, it has been speculated 
that a full term pregnancy at an early age reduces the probability of tumor formation. Some evidence to support this idea can be found in our study.

The dosis-response gradient between the number of months of breastfeeding and a decrease of risk for BC has been mainly associated with pre-menopausal women. The hypothesis that prolonged breastfeeding protects against $\mathrm{BC}$ was based on epidemiological evidence that countries with the lowest mortality rates due to $\mathrm{BC}$ also have prolonged breastfeeding as a common practice. ${ }^{10}$ The main finding of this study is the protective effect of breastfeeding, which is consistent with other epidemiological studies carried out in Mexico. ${ }^{9}$ Different hypothesis have been proposed to explain the protective effect of breastfeeding. The direct action of hypophysis and ovarian activity changes the post-partum hormonal status, which subsequently results in prolactine production, in turn reducing estrogenic activity through the suppression of ovulation. Given these results, the total accumulated exposure to estrogens would be reduced, inhibiting $\mathrm{BC}$ growth. Another possible mechanism is through changes in the ductal epithelial cells, through the mechanical dragging of carcinogens.

The association of hormonal contraceptive use with $\mathrm{BC}$ is controversial. Some studies suggest a greater risk in women who start using these drugs before age 25 , and with prolonged use. This study only considered the duration of hormonal contraceptives, independent of age at first delivery. A hereditary history of BC, in the maternal as well as the paternal line, increases women's risk of having this disease. Recent epidemiological and molecular biology studies have identified the genetic lesion that leads to a predisposition for $\mathrm{BC}$. The $\mathrm{BC} 1$ gene, which predisposes for pre-menopausal $\mathrm{BC}$, has been identified in the chromosome $17 q 21$ region (33). We found that women who reported having a first degree relative with $\mathrm{BC}$ had a 4 to 5 times higher risk of getting the disease. These findings are consistent with recent genetic analyses which show that cases that start early are much more likely to include hereditary susceptibility.

In this context, it is interesting to note that the risk factors of BC show a "mirrror image" in relation to the risk factors for CUCA. For example, the higher number of deliveries is a protective factor for $\mathrm{BC}$, while in CUCA is a risk factor.

It is possible that a bias occurred in the information if cases and controls had a preferred memory of an exposure, or if the interviewer induced certain responses. In this study, neither interviewed or the interviewers had knowledge of the study's hypothesis. It is possible that, particularly for the reproductive variables, with the exception of a history of breastfeeding, there could be an overestimation of the effect, since women in the control group had a history of high parity and early age for the birth of their first child, as well as lower socioeconomic level.

The purpose of classifying the women's menopausal status was to evaluate the possible effect of age and exposure to accumulated estrogens. This was considered important since the mortality pattern for $\mathrm{BC}$ in high risk populations is greater among postmenopausal women.

In conclusion, the main reproductive risk factors for BC are: early menarche, late menopause, nulliparity and low parity, absence of maternal breastfeeding, older age at birth of first child, prolonged use of hormonal contraceptives and family history of BC.

In Mexico is undergoing a social transition within which a demographic, epidemiological and risk factor transition is occurring. In this context, as we approach the twenty-first century, the demographic panorama is very different from that of 50 years ago, when the industrialization process was still relatively new and the increase in urban settlements had not reached important proportions. During this period, fertility rates, as well as general and child mortality, were reduced by more than $50 \%$. These events took on special importance in relation to what currently constitutes one of the country's main health problem, the cancer.

In this sense, $\mathrm{BC}$ constitutes a latent threat as a consequence of a significant increase in life expectancy, the reduction of the total annual growth rate, the beginning of what we now call the "aging of the population", as well as changes in life style, in particular a reduction in the practice of breastfeeding and decreased fertility rates.

This epidemiological study contributes to the identification of risk factors for BC described in the international literature, with specific reference to Mexican women. Breastfeeding appears to play an important role in protecting women from BC. Because of changes in women's lifestyles, lactation is decreasing in Mexico, and young women tend not to breastfeed or to shorten the duration of lactation (34). In association with the strong decline in the fertility rate, this decreasing trend in lactation may be responsible for the increasing incidence of BC observed in the Mexican population. Nevertheless, a better understanding of the physiological changes that occur during breastfeeding is necessary to determine the main mechanism by which it may protect women from BC. 


\section{REFEREN CES}

1. Bischoff $F Z, H$ ansen MF. Genetics of familial breast cancer. Cancer Bull 1993;45:476-82.

2. Bronfman $M$, Guiscafré $H$, Castro V, Castro R, Gutiérrez G. Medición de la desigualdad: una estrategia metodológica, análisis de las características socioeconómicas de la muestra. Arch Invest Med 1988;19:351-60.

3. Harris JR, Lippman ME, Veronesi H, Willet W. Breast cancer. N England J Med 1992;27:319-28.

4. Henderson IC. Risk factors for breast cancer development. Cancer 1993;17(6 Suppl):2127-40.

5. Hernández $M$, Lazcano $E$, Berumen J, Cruz A, Alonso $P$, González G. Human Papillomavirus 16-18 infection and cervical cancer in Mexico: a case-control study. Arch Med Res 1997;28:265-71.

6. Hsieh CC, Trichopolus D, Katsovyani K. Age and menarche, age at menopause, height and obesity as risk factors for breast cancer: association and interactions in an international case-control study. Int J Cancer 1990;46:796-800.

7. Kelsey JL, Gammon MD, John EM. Reproductive factors and breast cancer. Epidemiol Rev 1993;15:36-47.

8. Kroman N, Wohlfahrt J, Andersen KW, Mouridsen HT, Westergaard T, Melbye M. Parity, age at first childbirth and the prognosis of primary breast cancer. $\mathrm{Br} J$ Cancer 1998;78:1529-33.
9. López L, Bravo J, Poblano O, O rtega D. Reproductive determinants of breast cancer in Mexican women. Ann N Y Acad Sci 1997;837:537-50.

10. Lund E. Breast cancer mortality and the change in fertility risk factors at menopause: a prospective study of 800,000 Norwegian women. Epidemiology 1991;2:285-8.

11. Pike MC, Spicer DV, Dahmoush L. Estrogens, progestogens, normal breast cell proliferation and cancer risk factors. Epidemiol Rev 1993;15:17-35.

12. Secretaría de Salubridad y Asistencia. Compendio del registro histopatológico de neoplasias en México. Epidemiología. M éxico; 1998.

13. Stata corporation. Stata reference manual: stata release 3.1. College Station TX: Stata Corporation; 1993. USA 1993.

14. Tao SC, Yu MC, Ross RK, Xiu KW. Risk factors for breast cancer in chinese women of Beijing. Int J Cancer 1988;42:495-8.

15. Yuan JM, Yu MC, Ross RK, Gao YP, Henderson BE. Risk factors for breast cancer in Chinese women in Shangai. Cancer Res 1988;48:1949-53. 